\title{
The Collapse of the USSR as a Factor in the Delegitimization of the Ethnopolitical Statuses of Minorities \\ On the Example of South Ossetia
}

\author{
Inal B. Sanakoev ${ }^{1, *}$ Marina L. Ivleva ${ }^{2, a}$ Dina G. Alborova ${ }^{1, b}$ Lina T. \\ Kulumbegova ${ }^{1, c}$ \\ ${ }^{1}$ South Ossetian State University named after A. A. Tibilov, 8, Putina str., Tskhinval, Republic of South Ossetia \\ ${ }^{2}$ Peoples' Friendship University of Russia, 6, Miklukho-Maklaya str., Moscow, Russia \\ a Email: ivleva-ml@rudn.ru \\ ${ }^{b}$ Email: mariadement93@gmail.com \\ ${ }^{c}$ Email: linakulumbegova@mail.ru \\ ${ }^{*}$ Corresponding author. Email: inal59@mail.ru
}

\begin{abstract}
The article is devoted to the study of the processes of delegitimization of the ethno-political statuses of ethnic minorities in the territory of the former USSR. The goal is to find out the complex factors that contributed to this process and to study the local manifestations of this situation. The article analyzes the phenomenon of the disintegration of the state, the Russian-Ossetian cultural and historical tradition, the policy of the union center, as well as the ethno-political status of South Ossetia in the conditions of post-Soviet Georgia. The authors also consider the processes of delegitimization of ethnopolitical status of minorities in the context of nation-building in post-Soviet states.
\end{abstract}

Keywords: Ethnopolitical status, Ehno-national identity, Processes of delegitimization, Selfidentification, Ethno-federal hierarchy.

\section{INTRODUCTION}

Ethnic minorities on the territory of the former USSR are faced with a large-scale delegitimization of their ethnopolitical statuses. Such a situation inevitably led to the destabilization of their political and legal position and an increase in the general level of conflict throughout the post-Soviet space as a whole. In this regard, it seems relevant to consider the issue of the factors of such delegitimization and destabilization, to clarify the specific specifics of the phenomenon in its local manifestations, as well as the peculiarities of the course of this process.

*Fund: The study was carried out with the financial support of the Russian Foundation for Basic Research (RFBR) in the framework of the scientific research project («Ethnosocial identity at the intersection of cultures in the changing social reality in the post-Soviet space»). Project № 21-511-07002.

\section{THE PHENOMENON OF THE COLLAPSE OF THE STATE}

The disintegration of a multi ethnic state is a complex ethnopolitical phenomenon that has a powerful impact on all aspects of the life of the ethnic groups living in it, since behind the collapse of the state lies "the lack of legitimacy of government, which gives rise to civil wars, economic collapse, the collapse of health care and consumption systems, the problem of refugees, etc." [1]. The spread of this phenomenon in the 1990s in various regions of the world, including Europe (USSR, Yugoslavia, Czechoslovakia), has led to its more intensive study in science, in which the concept of "state disintegration" "has experienced a sharp rise in the conjuncture in recent years" [2]. This is connected, of course, with the fact that the theoretical and 
methodological approach to the analysis of the problem of the disintegration of the state "requires a more thorough study of the fundamental causes of this phenomenon" [3].

It is obvious that the disintegration of a multi ethnic state is accompanied by the destabilization and delegitimization of the ethnopolitical statuses of its constituent ethnic groups, which forces them to seek new forms of self-identification, including status ones. These processes are due to the influence of the main components of the decay process itself.

So, on the one hand, this is the destruction of the old identity, when "nation states lose their monopoly on the controlled national identity of their citizens" [4]. In this regard, in relation to the collapse of the USSR, the crisis and the subsequent destruction of Soviet identity appear as multidimensional and systemic phenomena. According to experts, the content side of the crisis of Soviet identity is very diverse: "the degeneration of the connecting ideology, the lack of faith of the elites, the weakening of socialization, the loss of faith in the historical mission of the state, disillusionment with ideals that have not been questioned before, the loss of confidence in the existing government, the inconformity of the state policy to the changed living conditions of citizens" [5].

It is obvious that the destruction of Soviet identity pushed ethnic groups to search for new forms of ethno-national self-identification, when the fall in confidence in the communist system led to the destruction of the ideal underlying statehood and "pushed many citizens, regardless of social status, nationality or confessional affiliation, to search for new worldview guidelines" [6]. At the same time, according to researchers, one of the possible vectors of new identification in the context of such largescale transformations can become the so-called "retro-identification" - a return to the primary sources of identity: "In a world dominated by such uncontrolled and disorderly changes, people tend to group around the primary sources of identity: religious, ethnic, territorial, national" [7].

\section{RUSSIAN-OSSETIAN CULTURAL AND HISTORICAL TRADITION}

South Ossetians, like many ethnic minorities of the former USSR, were deeply associated with Soviet identity. It was perceived by them as a general civil identity, and it rather successfully coexisted with ethno-national self-identification. The relatively rapid assimilation and acceptance of Soviet identity in
South Ossetia was explained by the fact that it was quite reasonably associated in the mass consciousness with Russian identity, at least from Russia. And the attitude towards Russia in South Ossetia, like in Ossetia as a whole, was based on a long-standing and strong Russian-Ossetian cultural and historical tradition, which was formed in line with at least two major components: military-political and ethnocultural.

In military-political terms, the Russian-Ossetian tradition was formed in the conditions of the formation of close allied relations between Russia and Ossetia. At the same time, it is interesting to note that the initiative to establish such relations often came from both sides, each of which was interested in this in its own way. For Russia, keen interest in Ossetia was primarily due to the benefits of its geostrategic location in the Central Caucasus region. And in this context, Ossetia was presented to the Russian authorities as a very convenient militarypolitical base for active expansion to the Caucasus and further south. Ossetia, for its part, was vitally interested in establishing allied relations with Russia in order to resettle the highlanders suffering from landlessness to the plain and to ensure their common security.

Ethnoculturally, the Russian-Ossetian tradition was formed in the context of a fairly intensive interaction of two cultures, with a clear preponderance, of course, of Russian influence. The ethnocultural influence of Russia on Ossetia, both North and South, was so active that it contributed to the formation of the Ossetian ethnocultural identity itself. One of the most important elements of this identity was Russian-Ossetian bilingualism, which contributed to the revival and flourishing of the ethnic culture of Ossetian society both in the south and in the north of Ossetia. Therefore, Ossetians in general and South Ossetians in particular easily accepted and assimilated practically any sociopolitical projects emanating from Russia. As the researchers emphasize: "They (the Ossetians) never betrayed Russia, no matter what happened in the capitals. They were loyal to the Russian Empire, the communist Soviet Union. Because they understood perfectly well: it is with Russia that they are on their way and Russia will protect them" [8].

\section{FACTORS OF DELEGITIMIZATION OF THE ETHNOPOLITICAL STATUS OF SOUTH OSSETIA}

The destruction of Soviet identity, as well as the collapse of the USSR in general, had a significant 
destructive effect on the population and political elite of South Ossetia, who perceived these processes as a threat to their identity. These sentiments contributed to the growth of frustrations in the socio-political sphere and the deepening of the processes of selfreflection, leading to an awareness of the need to search for new forms of self-identification, associated primarily with territory and ethnic status. The retroidentification, which was actualized in the South Ossetian ethno-national consciousness, turned out to be connected mainly with the origins of the formation and the specifics of the formation of the South Ossetian Autonomous Region (SOAO), which took place in the conditions of collisions that were significant for the South Ossetians during the period of the collapse of the Russian Empire and the formation of the USSR as a state.

Another component of the Soviet disintegration processes that contributed to the delegitimization and destabilization of the Southern Administrative District is the destruction of the Soviet ethno-federal national-state system.

In the 1920s in the USSR, a complex hierarchy of forms of national statehood was introduced depending on the degree of maturity of the ethnic community: union, autonomous republics, autonomous regions, national regions, when "the Soviet state was forced to recognize the subjectivity of ethnic groups through the formal (legal) approval of their various statuses" [9].

The Soviet ethno-federal system created on this principle contained obvious positive and negative aspects. So, on the one hand, it has in a certain way ordered the most complex interethnic contradictions in national regions, which often go back centuries and often lead to outbreaks of the most severe conflicts. This system undoubtedly helped to remove the most acute problems in the ethnic mosaic of the vast expanse of the Soviet Union. In this regard, it is obvious that at the initial stage the Bolsheviks managed to resolve the national question in Russia through the system of national-territorial entities.

However, on the other hand, the Soviet ethnofederal system also contained an obvious potential for conflict. Thus, the hierarchization of the ethnopolitical statuses of minorities actually legalized the supremacy of vertical relations of domination / subordination in society: the smaller "brothers" obeyed the middle ones, and those, in turn, obeyed the older brother. In addition, the position of ethnic groups, especially small ones, was complicated by the fact that, despite the complex hierarchy of ethnic statuses, "state policy towards peoples was based on the principle of unification of all social life, denial of the internal socio-political structure of the ethnic group" [10]. Such a policy inevitably produced social discontent and increased tensions in interethnic relations. Therefore, in the conditions of the collapse of the USSR, there were more than enough grounds for the aggravation of contradictions and a significant increase in the general level of conflict throughout the entire post-Soviet space. According to V.A. Tishkov, "the existing and persisting social, political and cultural hierarchy of ethnic groups in this region of the world (the territory of the USSR), as well as the repressive actions of the past regime against the peoples inhabiting the territory of the former USSR, are so great that there are more than there are enough grounds for interethnic contradictions, both at the personal and group levels" [11].

The collapse of Soviet ethnofederalism turned out to be extremely destructive for the South Administrative District. Built into a rigid hierarchy of Soviet ethnic statuses, the South Ossetian autonomy began to automatically lose its legitimacy and actually hung in the air. The autonomy management system, built according to the strict Moscow-TbilisiTskhinvali scheme, has ceased to function properly, endangering the socio-political stability in the South Ossetian Autonomous Okrug. So in 1988, the term of office of the Regional Council of People's Deputies expired, and the leadership of the South Ossetian Autonomous Okrug was unable to obtain permission to hold new elections to the supreme body of the autonomy either in Moscow or in Tbilisi. Therefore, after 1988, the supreme governing bodies of the South Administrative District were illegitimate. Moreover, the Supreme Soviet of the Georgian SSR already in the summer of 1990 , i.e. back in the conditions of the USSR, declared all laws and regulations adopted after 1922 to be null and void. Such acts automatically included legislative acts that legalized the status of the South Ossetian Autonomous Okrug in the Soviet ethno-federal system: the Decree of the Central Executive Committee and the Council of People's Commissars of the GSSR on the formation of the South Ossetian Autonomous Region of 1922 and the Law on the South Ossetian Autonomous Region of 1980, adopted by the Supreme Soviet of the GSSR.

The delegitimization of the ethnopolitical status of the South Ossetian Autonomous Okrug was significantly aggravated by the fact that, despite being a part of the Georgian SSR, the South Ossetian autonomy for more than 70 years of Soviet power was not fully integrated into the Georgian 
ethnopolitical space, neither politically, nor socioculturally, nor in socio-economic terms.

\section{POLICY OF THE UNION CENTER}

It is obvious that the uncertainty of the ethnopolitical status of South Ossetia in the context of the collapse of the USSR put the problem of its political fate on the agenda. In this regard, due to the prevailing circumstances, the further prospects of the South Administrative District, its preservation or liquidation, to a large extent began to depend, on the one hand, on the policy of the Union Center, which tried to regulate the process of the country's disintegration in a certain way, and, on the other, on the positions of the post-Soviet Georgian political elite, which headed for building an independent state.

The Union Center formally gave the autonomous formations in the USSR republics the right to unilaterally resolve issues of their status up to secession from the union republic. On April 3, 1990, the Supreme Soviet of the USSR was forced to adopt a law "On the procedure for resolving issues related to the secession of the union republic from the USSR". This law regulated the implementation of the constitutional right of the union republics to secede from the USSR and provided for a referendum and a five-year term. Article 3 of this law declared: "In a union republic, which has autonomous republics, autonomous regions and autonomous okrugs, a referendum is held separately for each autonomy. The peoples of the autonomous republics and autonomous formations retain the right to independently resolve the issue of staying in the USSR or in the seceding union republic, as well as to raise the issue of their state and legal status" [12].

However, in reality, such legislation did not become a working mechanism for the exit of the union republics from the USSR and the protection of the rights of autonomous entities in them. This law, like most other laws then adopted by the Union parliament, turned out to be stillborn. The impotence of the USSR leadership to ensure the operation of the USSR laws on the territory of the country provoked their complete disregard. And the autonomous formations of the union republics, continuing to be in the rigid system of the Soviet ethnic hierarchy, had minimal chances of free expression of their will, and the further fate of their statuses continued to largely depend on the policy of the republican authorities. Therefore, the political fate of the South Ossetian autonomy began to depend on the policy of the postSoviet Georgian political elite, which formed its own nation-building project.

\section{ETHNOPOLITICAL STATUS OF SOUTH OSSETIA IN THE CONDITIONS OF POST-SOVIET GEORGIA}

For the new Georgian elite, the Ossetian problem was, first of all, the problem of the possible integration of the South Ossetian Autonomous Okrug and the entire southern part of the Ossetian ethnos into the new Georgian state. In fact, under the new conditions, the question arose of how to integrate South Ossetia and other ethno-territorial formations of the former GSSR (Abkhazia and Adjara) into the national Georgian state, without causing discontent on their part, and at the same time to protect their own national interests. And in this regard, the situation had every chance to develop according to two possible scenarios.

The first way is negotiation. In this regard, since "non-dominant groups need special treatment to preserve their characteristics that distinguish them from the majority of the population" [13], the situation objectively required the development of new models of bilateral relations on a contractual basis and the creation, thus, of a new system of nationalstate devices of the Georgian state. Thus, the new Georgian elite could recognize and confirm the legitimacy of the South Ossetian Autonomous Okrug in the face of new political realities and thus agree to preserve the status quo in South Ossetia. Obviously, such a decision could be reached only on condition that the federalist structure of the Georgian SSR was preserved and the legitimacy of the autonomies that were part of it was recognized.

With regard to South Ossetia, the problem was solved by the fact that the entry of South Ossetia into independent Georgia could be ensured by "granting the status of an autonomous republic within Georgia on federal terms" [14]. This approach in general made it possible not to aggravate relations with autonomies and other ethnic minorities, which constituted up to $1 / 3$ of the population of the GSSR, to establish stable relations with them and to ensure "peaceful coexistence and mutual assistance of nations and ethnic minorities in Georgia" [15], since "protection of minorities actually means not protecting their interests, but protecting peace and security in the region" [16].

Such an approach would certainly contribute to the transformation of the autonomies into real allies of the titular majority in the matter of Georgian nation-building. Thus, it would be possible to consolidate all ethnic minorities and ethno-territorial 
entities, which created rather favorable preconditions for the re-establishment of the Georgian state. In this context, concerning South Ossetia, the Georgian side had certain opportunities due to the absence of open clashes during the Soviet period. This gave a real chance to develop bilateral relations along a negotiated path, which could turn the South Ossetians into real allies, avoid interethnic conflict and, ultimately, contribute to the early acquisition of longawaited independence by Georgia.

In this regard, it became extremely necessary to overcome all the negative consequences of Soviet artificial integration in the early 1920s. At the same time, the legitimate process of the new model of integration was possible through the development of new mutually acceptable conditions and options that presuppose the principle of voluntariness and respect for the interests of the parties. The main, in this case, undoubtedly remained the condition for the recognition of the South Ossetian status quo, regardless of the historical prerequisites for education and political orientation. Such recognition would make it possible to formulate certain legal conditions for South Ossetia's joining independent Georgia. In this case, Georgian and Ossetian interests had a real chance of being reconciled, since relations could be built on the basis of bargaining, which is very widespread in politics, on the principle "you are for me - I am for you". This approach guaranteed the contractual nature of future Georgian-Ossetian relations.

For example, the Georgian side in exchange for the preservation of autonomy and Russian-Ossetian bilingualism in South Ossetia, i.e. South Ossetian status quo, could ask South Ossetia to break off from the USSR and voluntarily join independent Georgia. This could find some support in political circles and among the population of South Ossetia, who were aware of the whole problematic nature of the integration of the autonomous region into the Russian Federation. Although it is difficult to predict the development of events in this scenario, however, the previous peaceful state of Georgian-Ossetian relations gave some chances for the success of such a "deal". In any case, such approaches, if not completely excluded, then minimized the risk of confrontation and conflict in interethnic relations and created good prerequisites for reaching a consensus on the Ossetian problem. As rightly in this regard, M.V. Jordan "only the observance of the principle of mutual consideration of the interests of the parties can prevent the beginning of the confrontation from sliding into open confrontation" [17].
The second way, which has been implemented in practice, is discriminatory. It was aimed at refusing to recognize the legitimacy of South Ossetia and other autonomous entities. In practice, this option provided for the complete destruction of the entire political and legal system of the Georgian SSR and the elimination of all ethno-territorial formations in Georgia. It also meant the inclusion of the population of Abkhazia, Ajaria and South Ossetia in the new Georgian state not as political autonomies as in the Soviet system, but as local Georgian territories. This course was outlined in order to create not a federalist, but a unitary Georgian state. This option of integrating minorities into the Georgian state in practice led to a sharp increase in discontent on their part. The forced integration of minorities, at the same time, inevitably contributed to the escalation of ethnic conflicts and the final disintegration of Georgia.

\section{CONCLUSION}

Thus, it can be stated that the actual delegitimization of the ethnopolitical statuses of minorities within the former USSR in general and South Ossetia in particular, took place due to the specifics of the processes of the disintegration of the polyethnic state, accompanied by the destruction of the previously unified Soviet identity and the Soviet ethno-federal system. Moreover, such delegitimization had its continuation and was aggravated by the specifics of the nation-building processes in the post-Soviet states, most of which, including Georgia, adhered to the so-called. an ethnonational doctrine focused on the creation of not a common civil nation, but an ethnonation.

\section{AUTHORS' CONTRIBUTIONS}

Inal Sanakoev: Made a significant contribution to the design and development of this area of investigation; Participated in writing and editing a draft version of the article; Approved the final version of the article for publication; Agreed to be responsible for all aspects of the study that may raise questions related to its accuracy, integrity and credibility.

Marina Ivleva: Made a significant contribution to the design and development of this area of investigation; Participated in editing a draft version of the article; Approved the final version of the article for publication; Agreed to be responsible for all aspects of the study that may raise questions related to its accuracy, integrity and credibility. 
Dina Alborova: Made a significant contribution to the collection, analysis and interpretation of data; Participated in writing a draft version of the article; Approved the final version of the article for publication; Agreed to be responsible for all aspects of the study that may raise questions related to its accuracy, integrity and credibility.

Lina Kulumbegova: Made a significant contribution to the collection, analysis and interpretation of data; Participated in editing a draft version of the article; Approved the final version of the article for publication; Agreed to be responsible for all aspects of the study that may raise questions related to its accuracy, integrity and credibility.

\section{REFERENCES}

[1] N. Piskunova. State disintegration: a local phenomenon or a global threat? On the question of the crisis in Somalia 1990-2008. Cosmopolis No. 3 (22). Autumn 2008. - P. 80.

[2] A. Horn. The order of the collapse of the state. On the issue of political discourse. Intelros magazine club. Socrates. No. 3, 2011. //http://www.intelros.ru/readroom/sokrat/sokrat3-aprel-2011/10476-poryadok-raspadagosudarstva.html Accessed 01.03.2018

[3] N. Piskunova. State disintegration: a local phenomenon or a global threat? On the question of the crisis in Somalia 1990-2008. Cosmopolis No. 3 (22). Autumn 2008. - P. 79.

[4] Yu. A. Kozhevnikova. The crisis of national identity in the globalizing world. Abstract of dissertation for the degree of candidate of philosophical sciences. Moscow State University named after M.V. Lomonosov, Moscow, 2012.http:

//cheloveknauka.com/krizis-natsionalnoyidentichnosti-v-globaliziruyuschemsya-mire Accessed 02.02.2017

[5] V.A. Turaev. The crisis of Soviet identity as a factor in the collapse of the USSR // Bulletin of the Irkutsk State University. Series "Geoarcheology. Ethnology. Anthropology" 2016. V. 15. P. 64-76. - P. 74.

[6] K.S. Gadzhiev. About the crisis of national identity // Peace and politics [Electronic resource]. - 7 Feb. 2013 \# 1. - URL: http://mirpolitika.ru/3499-o-krizise-nacionalnoyidentichnosti.html (date accessed: 08.10.2015)
[7] L.L. Melnikova. Identification crisis as a phenomenon of post-Soviet society // http://protestirui.ru/2012-12-21-17-01-44/103-23.12. Date of treatment $01 / 25 / 2017$.

[8] N. Narochnitskaya. Nobody needs Georgia without Abkhazia and South Ossetia! // "Komsomolskaya Pravda", 13.08.2008 // http://www.narochnitskaia.ru. Date of treatment 08/13/2008

[9] L.L. Khoperskaya. Modern ethnopolitical processes in the North Caucasus. - Rostov n / a, 1997.- P. 51

[10] L.L. Khoperskaya. Modern ethnopolitical processes in the North Caucasus. - Rostov n / D, 1997.- P. 53.

[11] V.A. Tishkov. On the nature of ethnic conflict // Free thought. - 1993. - No. 4. - P. 5.

[12] Law on the secession of the union republic from the USSR. The procedure for resolving issues related to the secession of the union republic from the USSR. http://voinru.com/2013/10/10/zakon-o-vyihodesoyuznoy-respubliki-iz-sssr/ Accessed 03/20/2017.

[13] M.A. Astvatsaturova. Diasporas in the Russian Federation: Formation and Management (North Caucasus Region). - Rostov-on-Don Pyatigorsk, 2002. - P. 255.

[14] Five years of the Republic of South Ossetia. Official materials. - Tskhinval, 1996.- P. 88.

[15] Gaprindashvili M. To the basics of forecasting, prevention and overcoming of existing and expected ethnopolitical conflicts in Georgia // Interethnic conflicts in the Caucasus: methods of overcoming them: Abstracts of the reports. at the International Conference 19-20.01.1995. M., 1995.- P. 50.

[16] Z. Skugbaty. As if peoples mattered. A critical Appraisal of 'Peoples' \& 'Minorities' from the International Human Rights Perspective \& Beyond. - The Hague, the Netherlands, 2000. P. 209.

[17] M.B. Jordan. Science of National Reconciliation // Social Sciences and Modernity. - 1992. - No. 4. - P. 113. 